\title{
The Investigation of the Relation between Service Quality in Higher Education and School Climate in terms of Different Variables
}

\author{
Soner ARIK
}

\author{
The Investigation of the Relation between Service \\ Quality in Higher Education and School Climate in \\ terms of Different Variables
}

\section{Abstract}

The purpose of this research is to determine whether the students' perceptions about the quality of the service in higher education and school climate differ significantly in terms of different variables. The research also aims to investigate whether there exists a significant relation between the quality of service in higher education and school climate. The study group of the research consists of 588 students at a state university in 2017-2018 academic years. The data was obtained through the 'Scale of Service Quality in Higher Education' and 'School Climate Scale'. It was concluded that there is a positive, medium and significant relation between service quality and school climate. The results also revealed that school climate perceptions differ significantly in terms of school type and university club membership variables while service quality perceptions differ significantly in terms of gender, order of school preference and grade level.

Key Words: Higher Education, School Climate, Service Quality
Yükseköğretimde Hizmet Kalitesi ve Okul İklimi Arasındaki İlişkinin Çeşitli Değişkenler Açısından İncelenmesi

Özet

$\mathrm{Bu}$ araştırmanın amacı, yükseköğretimde hizmet kalitesi ile okul iklimi algılarının çeşitli değişkenler açısından anlamlı farklılık gösterip göstermediğinin belirlenmesidir. Araştırmada ayrıca yükseköğretimde hizmet kalitesi ile okul iklimi arasında anlamlı bir ilişki olup olmadığının incelenmesi de amaçlanmaktadır. Tarama modelinde tasarlanan araştırmanın çalışma grubunu 2017-2018 akademik yılında bir devlet üniversitesinde öğrenim gören 588 öğrenci oluşturmaktadır. Araştırma verileri "Okul İklimi Ölçeği" ve "Yükseköğretimde Hizmet Kalitesi Ölçeği" vasıtasıyla toplanmıştır. Araştırmada, yükseköğretimde hizmet kalitesi ile okul iklimi arasında pozitif, orta düzeyde ve anlamlı bir ilişki olduğu sonucuna ulaşılmıştır. Araştırma sonuçları ayrıca, yükseköğretimde hizmet kalitesi algısı cinsiyete, tercih sıralarına ve sınıf düzeyine göre anlamlı farklılık gösterirken, okul iklimi ise okul türüne ve kulüp üyesi olma durumlarına göre anlamlı farklılık olduğunu ortaya çıkarmıştır.

Anahtar Kelimeler: Yükseköğretim, Okul İklimi, Hizmet Kalitesi

\section{Introduction}

In the 21st century, almost all countries' primary aim is to improve quality in education. One of the fundamental reasons for the improvement in the quality of education is the desire of countries to increase their levels of education. Because, education has a

* Soner ARIK, Dr., Niğde Ömer Halisdemir Üniversitesi, Yabancı Diller Yüksekokulu, sarik@ohu.edu.tr ORCID ID orcid.org / 0000-0002-5338-9238 
direct impact on the products and services presented in all other sectors. As stated by Uysal and Ersun-Aydemir (2016, p. 276), the cultural, economic and political development levels of communities are in direct proportionate to the importance they attach to education. Education is among the most powerful steps in poverty and inequality reduction and it also underlies economic development.

The level of knowledge and competency that human capital have and their ability to access and use knowledge is directly related to the quality of education and service received (Yokuş, Ayçiçek and Yelken, 2017, p. 4). In raising the human capital countries need for sustainable development and competition, higher education institutions are among the most important factors (Dlačić, Arslanagić, Kadić-Maglajlić, Marković \& Raspor, 2014, p. 141). In this regard, the services presented in universities as the institutions in which undergraduate and graduate education are given and individuals with the necessary fund of knowledge are raised are of great importance. Because, the services presented in these institutions play a crucial role in shaping the futures of not only those institutions but also other institutions and countries.

Service is a labour-intensive concept that is consumed the moment it is produced. It requires a continuous communication between the supplier and the consumer and it provides different benefits to the consumers (Uygur, 2007, p. 39). Service is an abstract concept that does not contain ownership and it is perceived as benefit or satisfaction by the consumers (Eser, 2007, p. 2; Küçükaltan, 2007, p. 32). Dörtyol (2012,p. 89) states that service should be considered and arranged on the basis of consumer viewpoints so that it can satisfy the consumers' desires and needs.

Corresponding to the general definition of service, the services given in universities are also abstract, they are produced and consumed concurrently and they are not homogenous (Şahin, 2011, pp. 60-61). Quality is defined as the conformity with aim, use, need and standard (Çabuk, 2018, p. 10). In the quality of service, which is defined as the gap between the service expected and presented, the emphasis is laid on the satisfaction of the consumers' expectations (Şahin, 2006, p. 34; Yousapronpaiboon, 2014, p. 1089). Quality of service wouldn't exist without the consumers' expectations about service (Dörtyol, 2012, p. 100). Although it is not considered ethical to define students as consumers, the fact that especially higher education has become a global marketplace causes students to be considered as customers (Mohamad Yusof, Hassan, Abdul Rahman \& Ghouri, 2012, pp. 36-37). Higher education institutes find themselves in fierce competition with others in this global marketplace. Therefore they lay great emphasis on the quality of services they offer, which is not surprising (O'Neill, 2000; Durvasula, Lysonski, \& Madhavi, 2011). Considering that there are so many providers worldwide in higher education sector, many universities feel the need to focus on their students as their customers and their opinions about the service they are offered (Wright, 2000, p. 39). In this context, determining the gap between the university students' expectations and percep- 
tions as to the services given by universities can contribute both to the determination of strategies for improving the quality of education and to the development of studentbased services (Aytar, Çil, Hoşbay Bayraktar ve Soylu, 2018: p. 247). Student-based, quality and innovative services that meet the expectations of students improve the students' perceptions about their schools (Koçoğlu, 2018), which enables a positive school climate.

School climate is directly related to many aspects of education process (Thapa, Cohen, Guffey ve Higgins-D'Alessandro, 2013: pp. 363-364).Those aspects that are defined as academic climate, social relations, security and institutional environment (Wang and Degol, 2016: p. 317) are exemplified as academic support, the quality of communication with teachers and peers, school security and structural organization (Zullig, Koopman, Patton and Ubbes, 2010: p. 141). School climate is based on the individuals' experiences in school life and reflects norms, aims, values, inter-personal relations, teaching and learning practices and organizational structures (Cohen, McCabe, Michelli and Pickeral, 2009 , p. 182). Meristo and Eisenschmidt (2014, p. 2) define school climate as the common beliefs and shared experiences among the internal stakeholders of schools. According to the definition by Hoy and Miskel (2005), school climate refers to the internal properties of school that differ from school to school and affect the behaviours of school members. Considering the definition of organizational climate made by Barutçugil (2004), it is understood that school climate represents the levels of the adoption of school's aims, acceptance of value judgements, conformance with school norms and display of the expected behaviours by the stakeholders of schools.

School climate, which is determined by the quality and properties of school, affects both academic motivation and academic achievement (Çelik, Terzi and Gültekin, 2017, p. 424). It is also stated in literature that school climate is a factor that determines the relation between service quality and student success (Uline and Tschannen-Moran, 2008, p. 66) and that it includes unwritten beliefs, values and behaviour patterns (Walsh, 2000). It is of great importance for the emotional, social and academic achievements of every single stakeholder of schools (Bradshaw, Waasdorp, Debnam and Johnson, 2014, p. 593; O'malley, Voight, Renshaw and Eklund, 2015, p. 4) and is based on the quality of relations between the stakeholders of schools (Demaray, Malecki and Jenkins, 2012). Bocchi, Dozza, Chianese and Cavrini, (2014, p. 4643) argue that positive school climate improves learning level along with students' academic achievements. In literature, it is revealed that positive school climate affects student success positively (Schagen and Hutchison, 2003; Berkowitz, Moore, Astor and Benbenishty, 2017). According to Ergün, Akcaoğlu and Ünver (2018, p. 482), school climate affects students' senses of belonging to school in addition to school reputation and student-friendly school environment will increase students' senses of belonging to school. Another factor that has an effect on students' senses of belonging to school is the quality of service given in schools and this makes it significant and necessary to take students' opinions about the quality of service given by their schools into consideration (Yokuş, Ayçiçek and Yelken, 2017, p. 4). All the stakeholders of 
Soner ARIK

schools and every variable related to schools affect school climate and academic achievement, which is among the primary goals of schools (Akbaba and Erdoğan, 2014, p. 225).

The primary purpose of this research is to determine whether there is a significant relation between university students' perceptions as to school climate, which is also referred as school identity, and service quality, which is one of the variables that affect school identity. In addition to this primary purpose, it is also aimed to test whether students' perceptions about school climate and service quality differ significantly in terms of different variables. In accordance with these purposes, the following research questions are determined:

1. What is the level of relation between service quality in higher education and school climate?

1.1. Do university students' perceptions as to the service quality in higher education and school climate differ in terms of gender?

1.2. Do university students' perceptions as to the service quality in higher education and school climate differ in terms of school type?

1.3. Do university students' perceptions as to the service quality in higher education and school climate differ in terms of order of school preference?

1.4. Do university students' perceptions as to the service quality in higher education and school climate differ in terms of grade level?

1.5. Do university students' perceptions as to the service quality in higher education and school climate differ in terms of university club membership?

1.6. Do university students' perceptions as to the service quality in higher education and school climate differ in terms of mother-father educational attainment?

\section{Method}

This research is designed in survey model because it aims to "describe a past or current situation as it is" (Karasar, 1999, p. 77). The study group of the research consists of 588 students who studied at a state university in 2017-2018 academic years.

The data were collected through School Climate Scale by Terzi (2015) and Service Quality Scale by Bektaş and Akman (2013), both of which are 5-likert type. School Climate Scale and Service Quality Scale consist of 17 and 46 items respectively. The researcher got permissions via e-mail for applying the scales for academic purposes. Exploratory factor analysis revealed that total variances explained by School Climate Scale and Service Quality Scale were 63\% and 48,50\% respectively. The Cronbach Alpha value of School Climate Scale was .839 and that of Service Quality Scale was .763. It was concluded that both scales were valid and reliable. 


\section{Findings}

The data were analysed through Kolmogorov-Smirnov test to determine whether they were normally distributed and it was found that they were not normally distributed. Therefore, Mann-Whitney $U$ test and Kruskall Wallis test were used for data analysis.

In Table 1, findings about the relation between the students' perceptions about service quality in higher education and school climate are presented.

Table 1. The Correlation Table Showing the Relation Between Service Quality In Higher Education And School Climate

\begin{tabular}{llc}
\hline \hline & & \multicolumn{2}{c}{ School Climate } \\
\hline \multirow{2}{*}{ Service Quality in Higher Education } & $\mathrm{r}$ &, 387 \\
\cline { 2 - 3 } & $\mathrm{p}$ &, 000 \\
\cline { 2 - 3 } & $\mathrm{n}$ & 588 \\
\hline
\end{tabular}

As it can be understood from the findings in Table 1, there is a positive, medium and significant relation between service quality in higher education and school climate $(r=, 387 ; p<0,05)$.

In Table 2, the data showing the difference between the students' perceptions about service quality in higher education and school climate in terms of gender are given.

Table 2. Mann Whitney U Test Showing the Difference Between Service Quality (SQ) In Higher Education And School Climate (SC) In Terms Of Gender

\begin{tabular}{|c|c|c|c|c|c|c|}
\hline Scale & Gender & $N$ & Mean Rank & Sum of Ranks & $Z$ & $p$ \\
\hline & Female & 336 & 308,88 & 103782,00 & & \\
\hline \multirow[t]{3}{*}{ SQ } & Male & 252 & 275,33 & 69384,00 & 2,372 & ,018 \\
\hline & Total & 588 & & & & \\
\hline & Female & 336 & 304,10 & 102176,00 & & \\
\hline \multirow[t]{2}{*}{ SC } & Male & 252 & 281,71 & 70990,00 & 1,584 & 113 \\
\hline & Total & 588 & & & & \\
\hline
\end{tabular}

Table 2 shows that service quality in higher education differs significantly in terms of gender $(z=2,372 ; p<0,05)$ while school climate does not differ $(z=1,584 ; p>0,05)$. Considering the mean ranks of the findings about service quality, it is seen that the difference is in favour of the female.

In Table 3, the data show the difference between the students' perceptions about service quality in higher education and school climate in terms of school type. 
Table 3. Kruskall Wallis Test Showing the Difference Between Service Quality (SQ) In Higher Education And School Climate (SC) In Terms Of School Type

\begin{tabular}{|c|c|c|c|c|c|c|}
\hline & School & $N$ & Mean Rank & $x^{2}$ & $p$ & $\begin{array}{c}\text { Source of Difference } \\
\text { (MWU) }\end{array}$ \\
\hline \multirow{4}{*}{ SQ } & Faculty & 296 & 300,04 & \multirow{4}{*}{,637 } & \multirow{4}{*}{ 727 } & \multirow{4}{*}{---- } \\
\hline & High-School (HS) & 120 & 288,37 & & & \\
\hline & $\begin{array}{l}\text { Vocational School } \\
\text { (VS) }\end{array}$ & 172 & 289,24 & & & \\
\hline & Total & 588 & & & & \\
\hline \multirow{4}{*}{ SC } & Faculty & 296 & 299,61 & \multirow{4}{*}{9,591} & \multirow{4}{*}{,008 } & \multirow{4}{*}{$\begin{array}{c}\text { Faculty-VS } \\
\text { HS-VS }\end{array}$} \\
\hline & High-School & 120 & 325,07 & & & \\
\hline & Vocational School & 172 & 264,37 & & & \\
\hline & Total & 588 & & & & \\
\hline
\end{tabular}

According to the findings in Table 3 school climate differs significantly in terms of school type $\left(X^{2}=9,591 ; p<0,05\right)$ while service quality does not significantly differ in terms of the same variable $\left(X^{2}=, 637 ; p>0,05\right)$. Mann Whitney $U$ test results showed that the difference found in school climate was in favour of the students in vocational school.

In Table 4, the data showing the difference between the students' perceptions about service quality in higher education and school climate in terms of order of school preference are presented.

Table 4. Kruskall Wallis Test Showing the Difference Between Service Quality (SQ) In Higher Education And School Climate (SC) In Terms Of Order Of School Preference

\begin{tabular}{|c|c|c|c|c|c|c|}
\hline & $\begin{array}{c}\text { Order of School } \\
\text { Preference }\end{array}$ & $N$ & Mean Rank & $X^{2}$ & $p$ & $\begin{array}{c}\text { Source of Difference } \\
(M W U)\end{array}$ \\
\hline \multirow{5}{*}{ SQ } & 1 & 110 & 301,14 & \multirow{5}{*}{9,030} & \multirow{5}{*}{,029 } & \multirow{5}{*}{$\begin{array}{l}2-4+ \\
3-4+\end{array}$} \\
\hline & 2 & 54 & 339,17 & & & \\
\hline & 3 & 30 & 349,10 & & & \\
\hline & $4+$ & 394 & 282,37 & & & \\
\hline & Total & 588 & & & & \\
\hline \multirow{5}{*}{ SC } & 1 & 110 & 294,90 & \multirow{5}{*}{1,522} & \multirow{5}{*}{ 677 } & \multirow{5}{*}{---- } \\
\hline & 2 & 54 & 318,24 & & & \\
\hline & 3 & 30 & 274,50 & & & \\
\hline & $4+$ & 394 & 292,66 & & & \\
\hline & Total & 588 & & & & \\
\hline
\end{tabular}

The findings in Table 4 show that service quality in higher education differs significantly in terms of order of school preference variable $\left(X^{2}=9,030 ; p<0,05\right)$ while school 
climate does not differ significantly in terms of the same variable $\left(X^{2}=1,522 ; p>0,05\right)$. It is understood from the Mann Whitney $U$ Test results that there are significant differences between the service quality perceptions of students who preferred their schools in the fourth order and over the fourth order. Also, a significant difference exists between the service quality perceptions of students who preferred their schools in the second order and third order. The differences are in favour of those who preferred their school in the second and third orders.

In Table 5, the data show the difference between the students' perceptions about service quality in higher education and school climate in terms of grade levels.

Table 5. Kruskall Wallis Test Showing the Difference Between Service Quality (SQ) In Higher Education And School Climate (SC) In Terms Of Grade Levels

\begin{tabular}{|c|c|c|c|c|c|c|}
\hline & $\begin{array}{l}\text { Grade } \\
\text { Level }\end{array}$ & $N$ & Mean Order & $x^{2}$ & $p$ & $\begin{array}{c}\text { Source of Difference } \\
\text { (MWU) }\end{array}$ \\
\hline \multirow{4}{*}{ SQ } & 1 & 154 & 332,03 & \multirow{4}{*}{11,697} & \multirow{4}{*}{,003 } & \multirow{4}{*}{$1-2$} \\
\hline & 2 & 418 & 279,24 & & & \\
\hline & 3 & 16 & 332,00 & & & \\
\hline & Total & 588 & & & & \\
\hline \multirow{4}{*}{$\mathrm{SC}$} & 1 & 154 & 291,64 & \multirow{4}{*}{1,719} & \multirow{4}{*}{,423 } & \multirow{4}{*}{---- } \\
\hline & 2 & 418 & 293,46 & & & \\
\hline & 3 & 16 & 349,13 & & & \\
\hline & Total & 588 & & & & \\
\hline
\end{tabular}

According to Table 5, service quality perceptions differ significantly in terms of grade level variable $\left(X^{2}=11,697 ; p<0,05\right)$ but school climate perceptions do not differ significantly in terms of the same variable $\left(X^{2}=1,719 ; p>0,05\right)$. The Mann Whitney $U$ test results show that the difference in service quality perceptions is between the students studying at 1 st and 2 nd grades and that the difference is in favour of students at 1 st grade.

In Table 6, the data showing the difference between the students' perceptions about service quality in higher education and school climate in terms of accommodation and mother's educational attainment variables are given. 
Table 6. Kruskall Wallis Test Showing the Difference between Service Quality (SQ) In Higher Education And School Climate (SC) In Terms Of Accommodation And Mother's Educational Attainment Variables

\begin{tabular}{|c|c|c|c|c|c|c|}
\hline & Accommodation & $N$ & Mean Rank & $x^{2}$ & $p$ & $\begin{array}{c}\text { Source of Difference } \\
(\mathrm{MWU})\end{array}$ \\
\hline \multirow{4}{*}{ SQ } & Dormitory & 432 & 285,77 & \multirow{4}{*}{4,333} & \multirow{4}{*}{ 115 } & \multirow{4}{*}{---} \\
\hline & Home with friends & 78 & 316,65 & & & \\
\hline & Home with family & 78 & 320,71 & & & \\
\hline & Total & 588 & & & & \\
\hline \multirow{5}{*}{ SC } & Dormitory & 432 & 296,31 & \multirow{4}{*}{2,454} & \multirow{4}{*}{ 293 } & \multirow{4}{*}{----} \\
\hline & Home with friends & 78 & 269,04 & & & \\
\hline & Home with family & 78 & 309,96 & & & \\
\hline & Total & 588 & & & & \\
\hline & $\begin{array}{l}\text { Mother's Educa- } \\
\text { tional Attainment }\end{array}$ & $\mathrm{N}$ & Mean Rank & $x^{2}$ & $\mathrm{p}$ & $\begin{array}{c}\text { Source of Difference } \\
\text { (MWU) }\end{array}$ \\
\hline \multirow{7}{*}{ SQ } & Illiterate & 40 & 312,10 & \multirow{7}{*}{3,012} & \multirow{7}{*}{ 698 } & \multirow{7}{*}{---} \\
\hline & Primary School & 312 & 289,77 & & & \\
\hline & Secondary School & 114 & 313,48 & & & \\
\hline & Lycee & 100 & 283,20 & & & \\
\hline & Bachelor's Degree & 18 & 292,83 & & & \\
\hline & Post-graduate & 4 & 236,50 & & & \\
\hline & Total & 588 & & & & \\
\hline \multirow{7}{*}{ SC } & Illiterate & 40 & 287,80 & \multirow{7}{*}{3,030} & \multirow{7}{*}{,695 } & \multirow{7}{*}{---- } \\
\hline & Primary School & 312 & 287,99 & & & \\
\hline & Secondary School & 114 & 302,69 & & & \\
\hline & Lycee & 100 & 299,22 & & & \\
\hline & Bachelor's Degree & 18 & 318,94 & & & \\
\hline & Post-graduate & 4 & 408,00 & & & \\
\hline & Total & 588 & & & & \\
\hline
\end{tabular}

As it can be understood from the findings in Table 6 , service quality perceptions $\left(X^{2}=4,33 / 3,01 ; p>0,05\right)$ and school climate perceptions $\left(X^{2}=2,454 / 3,03 ; p>0,05\right)$ do not differ significantly in terms of either accommodation or mother's educational attainment variables.

In Table 7, the data show the difference between the students' perceptions about service quality in higher education and school climate in terms of university club membership. 
Table 7. Mann Whitney U Test Showing the Difference Between Service Quality (SQ) In Higher Education And School Climate (SC) In Terms Of University Club Membership

\begin{tabular}{|c|c|c|c|c|c|c|}
\hline Scale & $\begin{array}{c}\text { Club Member- } \\
\text { ship }\end{array}$ & $N$ & Mean Rank & Sum of Means & $Z$ & $p$ \\
\hline \multirow{3}{*}{ SQ } & Yes & 136 & 281,10 & 38230,00 & \multirow{3}{*}{,976 } & \multirow{3}{*}{,329 } \\
\hline & No & 450 & 297,25 & 133761,00 & & \\
\hline & Total & 586 & & & & \\
\hline \multirow{3}{*}{ SC } & Yes & 136 & 348,63 & 47414,00 & \multirow{3}{*}{4,340} & \multirow{3}{*}{,000 } \\
\hline & No & 450 & 276,84 & 124577,00 & & \\
\hline & Total & 586 & & & & \\
\hline
\end{tabular}

According to Table 7, service quality perceptions do not differ significantly in terms of university club membership variable. On the other hand, school climate perceptions of students differ significantly in terms of the same variable and the means ranks as to school climate show that the difference is in favour of the students who are members of a club at university.

In Table 8, the data showing the difference between the students' perceptions about service quality in higher education and school climate in terms of the type of lycee from which the participants graduated are presented.

Table 8. Mann Whitney U Test Showing the Difference Between Service Quality (SQ) In Higher Education And School Climate (SC) In Terms Of The Type Of Lycee The Participants Graduated From

\begin{tabular}{|c|c|c|c|c|c|c|}
\hline Scale & $\begin{array}{c}\text { Type of } \\
\text { Lycee }\end{array}$ & $N$ & Mean Rank & Sum of Means & $Z$ & $p$ \\
\hline \multirow{3}{*}{ SQ } & State & 526 & 292,28 & 153737,00 & \multirow{3}{*}{ 341 } & \multirow{3}{*}{,221 } \\
\hline & Private & 56 & 284,21 & 15916,00 & & \\
\hline & Total & 582 & & & & \\
\hline \multirow{3}{*}{ SC } & State & 526 & 291,00 & 153065,00 & \multirow{3}{*}{,733 } & \multirow{3}{*}{,825 } \\
\hline & Private & 56 & 296,21 & 16588,00 & & \\
\hline & Total & 582 & & & & \\
\hline
\end{tabular}

The findings in Table 8 show that students' perceptions about neither service quality $(z=, 341 ; p>0,05)$ nor school climate differ $(z=, 733 ; p>0,05)$ significantly in terms of type of lycee from which the participants graduated. 
In Table 9, the data show the difference between the students' perceptions about service quality in higher education and school climate in terms of father's educational attainment.

Table 9. Kruskall Wallis Test Showing the Difference Between Service Quality (SQ) In Higher Education And School Climate (SC) In Terms Of Father's Educational Attainment

\begin{tabular}{|c|c|c|c|c|c|c|}
\hline Scales & $\begin{array}{l}\text { Father's Educa- } \\
\text { tional Attainment }\end{array}$ & $N$ & Mean Rank & $x^{2}$ & $p$ & $\begin{array}{c}\text { Source of Differ- } \\
\text { ence } \\
(M W U)\end{array}$ \\
\hline \multirow{7}{*}{ SQ } & Illiterate & 12 & 125,67 & \multirow{7}{*}{20,959} & \multirow{7}{*}{,001 } & \multirow{3}{*}{$\begin{array}{c}\text { Illiterate-Primary } \\
\text { School }\end{array}$} \\
\hline & Primary School & 182 & 283,05 & & & \\
\hline & Secondary School & 184 & 311,61 & & & \\
\hline & Lycee & 132 & 296,61 & & & \multirow{2}{*}{$\begin{array}{c}\text { Illiterate- } \\
\text { Secondary School }\end{array}$} \\
\hline & Bachelor's Degree & 76 & 311,00 & & & \\
\hline & Post-graduate & 2 & 9,50 & & & \multirow[b]{2}{*}{ Illiterate-Lycee } \\
\hline & Total & 588 & & & & \\
\hline \multirow{7}{*}{ SC } & Illiterate & 12 & 220,33 & \multirow{7}{*}{14,527} & \multirow{7}{*}{,013 } & \multirow{7}{*}{$\begin{array}{c}\text { Illiterate- } \\
\text { Secondary Schoo } \\
\text { Illiterate-Lycee }\end{array}$} \\
\hline & Primary School & 182 & 277,26 & & & \\
\hline & Secondary School & 184 & 316,89 & & & \\
\hline & Lycee & 132 & 312,27 & & & \\
\hline & Bachelor's Degree & 76 & 268,68 & & & \\
\hline & Post-graduate & 2 & 56,50 & & & \\
\hline & Total & 588 & & & & \\
\hline
\end{tabular}

According to Table 9, service quality $\left(X^{2}=20,959 ; p<0,05\right)$ and school climate $\left(X^{2}=14,527 ; p<0,05\right)$ perceptions differ significantly in terms of father's educational attainment variable. Mann Whitney $U$ test results show that the difference is against students who fathers are illiterate in both service quality and school climate.

\section{Discussion and Results}

The findings of the research show that there is a positive, medium and significant relation between service quality in higher education and school climate. As a result, it can be claimed that the quality of the service given in higher education institutions also affects school climate. This result coincides with Erdoğan and Akbaba's (2014) view that all the variables related to school affect school climate positively or negatively.

The findings in terms of gender show that university students' perceptions about service quality in higher education differ significantly in favour of women. In other words, female university students are more satisfied with the quality of the services given by 
their universities, which corresponds to the results of the study by Çokluk-Bökeoğlu and Yılmaz (2007) who revealed that the means of female university students' perceptions about the quality of services in higher education are high in comparison with those of male students. On the other hand, the result is inconsistent with the results of the studies conducted by Yokuş, Ayçiçek and Yelken (2017) and Aktel, Davras and Çetinceli (2017). According to Yokuş, Ayçiçek and Yelken (2017), the faculty of education students' perceptions about quality of service in higher education do not differ significantly in terms of gender. In contrast to the results of both studies, Aktel, Davras and Çetinceli (2017) revealed that male university students were more satisfied with the quality of the services given by their universities.

The results of this research about the perceptions of students on school climate show that there is no significant difference between the means of male and female students. This result is consistent with the results of the study by Çelik, Terzi and Gültekin (2017), who are among the few researchers who investigated school climate in higher education. The researchers also revealed that university students' perceptions about school climate were similar irrespective of their genders. Similarly, the results of the study by Tavşanlı, Birgül and Oksal (2016) found that gender did not predict any sub-dimensions of students' perceptions about school climate. On the other hand, there are also studies in literature whose results contradict with the results of this research and reveal that female students' perceptions about school climate are more positive than those of male ones (Terzi, 2015; Özdemir, Sezgin, Şirin, Karip and Erkan, 2010; Doğan, 2012; Saraç, 2015; Aydın, 2010; Doğan, 2011; Akman, 2010; Demir, 2008; Kılıç, 2010 and Bahçetepe, 2013). Among these studies, the one by Terzi (2015) showed a similar result to the results of this research only in the learning environment dimension of school climate.

No significant difference was found between the service quality perceptions of students in terms of school type. However, it was found that perceptions of high school students about school climate were more positive than those of vocational school or faculty students. This result couldn't be discussed within the context of literature as no research comparing students' perceptions about service quality in higher education and school climate on the basis of school type could be found in literature.

Students' perceptions about the quality of service in higher education were compared in terms of students' order of school preference. It was found that the perceptions of students who preferred their school in the second and third order were more positive than those of students who preferred their schools in the fourth or further orders respectively. On the other hand, the results of the research revealed that students' perceptions about school climate were not affected by their orders of school preference. These results couldn't be discussed within the context of literature as any researches comparing students' perceptions about service quality and school climate on the basis of order of school preference couldn't be found in literature. 
It was tested whether students' perceptions about service quality in higher education and school climate differed significantly in terms of accommodation, mother's educational attainment and type of school they graduated. The results revealed that none of these variables predicted students' perceptions about service quality in higher education and school climate. The results were similar to the results of a study which found that students' levels of satisfaction with their departments did not differ significantly in terms of type of school they graduated (Ayık, Özdemir and Yavuz, 2007). On the other hand, the results of this research are inconsistent with the results of the study by Saraç (2015) which revealed that mother's educational attainment level predicted secondary school students' perceptions about school climate.

The research tested whether students' club memberships at university predicted their perceptions about the quality of service in higher education and school climate. According to the results, their school climate perceptions differed significantly in terms of university club membership variable while there was no significant difference in their perceptions about the quality of service in higher education. The analysis of the source of difference in school climate perception showed that those who were members of any university club had more positive perceptions. These results couldn't be discussed within the context of literature as any researches comparing students' perceptions about service quality and school climate on the basis of order of university club membership variable couldn't be found in literature.

The results of the study revealed that students' perceptions about the quality of service in higher education and school climate differed significantly in terms of father's educational attainment. According to these results, it was found that the perceptions of students whose fathers were illiterate were more negative than those of other students. These results contradict with results of the study by Saraç (2015), who found that the school climate perceptions of the students whose fathers were primary school graduates were more positive in terms of the supportive teacher behaviours and successorientedness sub-dimensions while those of the students whose fathers were literate were higher in terms of peer interaction and safe learning environment sub-dimensions, which partly coincides with the results of this research.

In the research, a significant difference was found between students' perceptions about the quality of service in higher education in terms of grade level. The results showed that the students who studied at the $1^{\text {st }}$ grade had more positive perceptions than did those who studied at the $2^{\text {nd }}$ grade. Yokuş, Ayçiçek and Yelken (2017) found a similar result. However, in contrast to the results of this research, they revealed that the difference was in favour of the students at $3^{\text {rd }}$ grade, not of those at $1^{\text {st }}$ grade. Beaumont (2012) also asserted a similar result and stated that, being affected by such factors as reputation and performance, students' perceptions about service quality may differ as years pass during their higher education period. 
The results of the research showed that no significant difference existed between students' perceptions about school climate in terms of grade levels. This result coincided with the results of the study bu Tavşanlı, Birgül and Oksal (2015). Similarly, Saraç (2015) also found in his study on secondary school students that students' perceptions about school climate differed in terms of grade level. On the other hand, Terzi and Uyangör (2017) revealed that the school climate perceptions of students who studied at the $4^{\text {th }}$ grade at the faculty of education were more positive in comparison with those of students at other grade levels and this is inconsistent with the result of this research.

\section{Suggestions}

There are studies in literature which suggest that school climate affects academic achievement negatively of positively. A result of this research reveals that there is a positive significant relation between the students' perceptions about the quality of service and school climate. From this viewpoint, it can be stated that students' levels of satisfaction with the quality of service they receive may also affect their academic achievements. Therefore, higher education institutions are recommended to evaluate the levels of their students' satisfaction with the quality of services and to make improvements in the quality of services they give accordingly.

Although there are different results in literature, the results of this research reveal a difference in the perceptions of service quality in higher education in terms of gender. Thus, it is recommended that higher education institutions should evaluate the results of the satisfaction surveys they apply taking gender variable into consideration so that the changes and improvements they make in their services will contribute to the improvement of the quality of educational services.

The result that school climate perceptions differ significantly in terms of school type appears to be an important criteria to be specifically considered in both evaluating the results of any school climate assessment practices and making changes and arrangements according to those results. Thus, higher education institutions should evaluate their students' perceptions about school climate not only in general terms but also on the basis of school types. It is also suggested for further studies that school climate perceptions of university students should be investigated within its sub-dimensions in terms of school type variables.

Higher education institutions should set up as many and varied clubs as possible and develop processes to encourage their students to join those clubs. Because the results of this research show that being a member of a club at university leads to positive perceptions about school climate which, in turn, is thought to result in better academic achievement. On the other hand, no research could be found in literature that tests whether there is a direct relation between university club membership and academic achievement. Therefore, it is suggested that researchers should conduct studies with such purpose. 
It was concluded that students who did not prefer their schools within their first three orders of preference were less satisfied with the quality of the service their school gave. It is suggested that a study should be conducted in order to discover the reasons for this result in detail as such a study could both make a significant contribution to the literature and provide a different perspective for the higher education institutions in their efforts to assess the quality of the services they present.

\section{References}

Akbaba, A. ve Erdoğan, H. (2014). Okul yöneticileri ve öğretmen görüşlerine göre okul ikliminin oluşmasi, Akademik Sosyal Araştırmalar Dergisi, 2(5): 211-227.

Akman, Y. (2010). İlköğretim ikinci kademe öğrencilerinin şiddet ve okul iklimi algıları arasındaki ilişki (Yayımlanmamış yüksek lisans tezi). Gazi Üniversitesi, Ankara.

Aktel, M., Davras, Ö. ve Çetinceli, E. (2017). Meslek yüksekokulu eğitim hizmet kalitesinin öğrenci memnuniyet ölçeği ile değerlendirilmesi: Isparta MYO örneği [Assessing Vocational School's Education Service Quality via Student Satisfaction Scale: The Case Study of Isparta]. 4. Ulusal Meslek Yüksekokulları Sosyal ve Teknik Bilimler Kongresi Mehmet Akif Ersoy Üniversitesi, 1113 Mayıs 2017, Burdur/ Türkiye.

Aydın, F. (2010). Özel okullardaki okul ikliminin öğretmen ve öğrenci algılarına göre incelenmesi (Yayınlanmamış yüksek lisans tezi). Yeditepe Üniversitesi, İstanbul.

Ayık, Y.Z., Özdemir, A. ve Yavuz, U. (2007). Lise türü ve mezuniyet başarısının kazanılan fakülte ile ilişkisinin veri madenciliği tekniği ile analizi. Atatürk Üniversitesi Sosyal Bilimler Enstitüsü Dergisi. 10(2): 441-454.

Aytar, O., Çil, U., Hoşbay Bayraktar, D. ve Soylu, Ş. (2018). Hizmet kalitesi ölçüm yöntemleri ve de stratejik yönetim bilgi kaynaği yöntem önerisi. Journal of Higher Education and Science/Yükseköğretim ve Bilim Dergisi, 8(2): 245-253.

Bahçetepe, Ü. (2013). Illköğretim sekizinci sını öğrencilerinin akademik başarıları ile algıladıkları okul iklimi arasındaki ilişki (Yayınlanmamış Yüksek Lisans Tezi). İstanbul Üniversitesi, İstanbul.

Barutçugil, i. (2004). Stratejik İnsan Kaynakları Yönetimi, İstanbul: Kariyer Yayınları.

Beaumont, D.J. (2012). Service quality in higher education: The students' viewpoint. University of Manchester, Manchester Business School, Manchester, UK.

Bektaş, H., ve Akman, S.U. (2013). Yükseköğretimde hizmet kalitesi ölçeği: güvenilirlik ve geçerlilik analizi. Ekonometri ve Istatistik e-Dergisi, (18):116-133. 
Berkowitz, R., Moore, H., Astor, R. A., \& Benbenishty, R. (2017). A research synthesis of the associations between socioeconomic background, inequality, school climate, and academic achievement. Review of Educational Research, 87(2), 425-469.

Bocchi, B., Dozza, L., Chianese, G., \& Cavrini, G. (2014). School climate: Comparison between parents' and teachers' perception. Social and Behavioural Sciences, 116, 4643-4649.

Bradshaw, C.P., Waasdorp, T.E., Debnam, K.J., \& Johnson, S.L. (2014). Measuring school climate in high schools: A focus on safety, engagement, and the environment. Journal of School Health, 84(9), 593-604. doi:10.1111/josh.12186

Cohen, J., McCabe, L., Michelli, N.M., \& Pickeral, T. (2009). School climate: Research, policy, practice, and teacher education. Teachers College Record, 111(1): 180-213.

Çabuk, S.N. (2018). Peyzaj mimarlığı eğitiminde kalite yönetimi ve akreditasyon. Turkish Journal of Landscape Research, 1(1): 9-19.

Çelik, H., Terzi, A.R., ve Gültekin, S. (2017). Üniversite öğrencilerinin akademik motivasyonları ve okul iklimi ilişkisi. Akademik Sosyal Araştırmalar Dergisi, 5(48): 422-434.

Çokluk-Bökeoğlu, Ö., ve Yılmaz, K. (2007). Üniversite öğrencilerinin fakülte yaşamının niteliğine ilişkin görüşlerinin çeşitli değişkenler açısından incelenmesi. Ankara Üniversitesi Eğitim Bilimleri Fakültesi Dergisi, 40(2): 179-204.

Demaray, M., Malecki, C. \& Jenkins, L. (2012). Social support in the lives of students involved in aggressive and bullying behaviours, in: S. Jimerson, A. Nickerson, M. Mayer ve M. Furlong (Eds) Handbook of school violence and school safety: International research and practice, (2nd ed)(New York, Routledge), 57-67.

Demir, A. (2008). Ortaöğretim okullarında okul iklimi ile öğretmen performansları arasındaki ilişki (Yayımlanmamış yüksek lisans tezi).Yeditepe Üniversitesi, İstanbul.

Dlačić, J., Arslanagić, M., Kadić-Maglajlić, S., Marković, S., \& Raspor, S. (2014). Exploring perceived service quality, perceived value, and repurchase intention in higher education using structural equation modelling. Total Quality Management \& Business Excellence, 25(1-2), 141157.

Doğan, S. (2011). Genel lise öğrencilerinin algılarına göre okul tahripçiliği ile okul iklimi arasındaki ilişki (Yayınlanmamış doktora tezi). Gazi Üniversitesi, Ankara.

Doğan, S. (2012). Lise öğrencilerinin okul iklimi algıları. Adıyaman Üniversitesi Sosyal Bilimler Enstitüsü Dergisi, 5 (10): 55-92.

Dörtyol, i.T. (2012). Ulusal kültürün algılanan hizmet kalitesi ve algılanan müşteri değeri üzerindeki etkisi: Turizm sektöründe bir araştırma. (Yayımlanmamış Doktora Tezi), Cumhuriyet Üniversitesi Sosyal Bilimler Enstitüsü Işletme Ana Bilim Dalı, Sivas. 
Soner ARIK

Durvasula, S., Lysonski, S., \& Madhavi, A.D. (2011). Beyond service attributes: Do personal values matter? Journal of Services Marketing, 25(1), 33-46.

Ergün, M., Akcaoğlu, M.Ö., ve Ünver, N. (2018). Üniversite itibari, markalaşma ve öğrencilerde aidiyet duygusu. Pegem Atıf İndeksi, 473-488, DOI: 10.14527/9786052412480.31.

Eser, Z. (2007). Hizmetlerde Pazarlama Illetişim, Ankara: Siyasal Kitabevi.

Güçkıran, R.Y. (2008). Illköğretim okulu öğrencilerinin okul iklimi algıları ile saldırganlık düzeyleri arasındaki ilişki. (Yayınlanmamış Yüksek Lisans Tezi), Yeditepe Üniversitesi Sosyal Bilimler Enstitüsü, İstanbul.

Hoy, W.K. \& Miskel, C. (2005). Education administration: Theory, research, and practice, (7th edn), New York: McGraw-Hill.

Karaman, Ö. ve Yurtal, F. (2015). Students' perceptions of school climate where violence is prevalent in schools. Elementary Education Online, 14(2): 421-429.

Karasar, N. (1999). Bilimsel Araştırma Yöntemi. Ankara: Nobel Yayın Dağıtım.

Kılıç, S. (2010). Akran istismarının ilköğretim öğrencilerinin okul iklimi algıları üzerindeki etkisi (Yayınlanmamış yüksek lisans tezi). Beykent Üniversitesi, İstanbul.

Koçoğlu, C.M. (2018). Turizm eğitimi veren kurumlarının itibar bileşenlerinin öğrencilerin memnuniyeti ve tavsiye etme davranişi üzerindeki etkisi. Eskişehir Osmangazi Üniversitesi iiBF Dergisi, 13(2): 23-44.

Küçükaltan, D. (2007). Hizmet Kalitesi Kavramlar, Yaklaşımlar ve Uygulamalar, Gümüşoğlu, Ş., Pırnar, I. ve Akan, P. ve Akbaba, A. (Ed.), Ankara: Detay Yayıncılık.

Meristo, M., \& Eisenschmidt, E. (2014). Novice teachers' perceptions of school climate and selfefficacy. International Journal of Educational Research, 67: 1-10, doi:10.1016/j.ijer.2014.04.003

Mohamad Yusof, A.R., Hassan, Z., Abdul Rah man, S., \& Ghouri, A.M. (2012). Educational service quality at public higher educational institutions: A proposed framework and importance of the sub - dimensions. International Journal of Economics Business and Management Studies, $1(2), 36-49$

O'malley, M., Voight, A., Renshaw, T.L., \& Eklund, K. (2015). School climate, family structure, and academic achievement: A study of moderation effects. School Psychology Quarterly, 30(1): 142.

O'Neill, M. (2000). The role of perception in disconfirmation models of service quality. Quality Focus, 4(2), 46-59. 
Özdemir, S., Sezgin, F., Şirin, H., Karip, E. ve Erkan, S. (2010). Illköğretim okulu öğrencilerinin okul iklimine ilişkin algılarını yordayan değişkenlerin incelenmesi. Hacettepe Üniversitesi Eğitim Fakültesi Dergisi, 38: 213-224.

Saraç, K. (2015). Okul ikliminin ortaokul öğrencilerinin algılarına göre değerlendirilmesi (Yayımlanmamış Yüksek Lisans Tezi), ESOGÜ, Eğitim Bilimleri Enstitüsü, Eskişehir.

Şahin, D. (2006). Otel aydınlatmasında genel ilkeler ve otel yatak odaları için bir değerlendirme. (Yayınlanmamış Yüksek Lisans Tezi). Yıldız Teknik Üniversitesi Fen Bilimleri Enstitüsü, İstanbul.

Şahin, G.G. (2011). Üniversite düzeyinde turizm eğitiminde hizmet kalitesi beklenti ve algısına yönelik Ankara'da bir araştırma. İşletme Araştırmaları Dergisi, 3(4): 49-65.

Tavşanlı, Ö.F., Birgül, K., ve Oksal, A. (2016). Ortaokul öğrencilerinin okul iklimine yönelik algılarını yordayan değişkenlerin incelenmesi. Electronic Turkish Studies, 11(9): 821-838.

Terzi, A.R., ve Uyangör, N. (2017). Eğitim fakültesi öğretmen adaylarının akademik motivasyonları ve algıladıkları okul iklimi ilişkisi. Journal of Current Researches on Social Sciences, 7(4): 185196.

Terzi, A.R. (2015). School Climate Perceptions of University students, Education in the 21st Century: Theory and Practice, (Ed: İ. Koleva, R.Efe, E.Atasoy, B.Kostova), Sofya: St. Kliment Ohridski University Press, 61-68.

Thapa, A., Cohen, J., Guffey, S., \& Higgins-D’Alessandro, A. (2013). A review of school climate research. Review of Educational Research, 83(3): 357-385.

Uline, C., \& Tschannen-Moran, M. (2008). The walls speak: The interplay of quality facilities, school climate, and student achievement. Journal of Educational Administration, 46(1): 55-73. doi:10.1108/09578230810849817

Uygur, S. (2007). Turizm Pazarlaması, Ankara: Nobel Yayın Dağıtım.

Uysal, D. ve Aydemir, E. E. (2016). Türkiye'de yükseköğretim kavramı ve yükseköğretimin istihdam ve ekonomiye etkisinin analizi. Selçuk Üniversitesi Sosyal Bilimler Enstitüsü Dergisi, (35), 275284.

Wang, M.T., \& Degol, J.L. (2016). School climate: A review of the construct, measurement, and impact on student outcomes. Educational Psychology Review, 28(2): 315-352.

Welsh, W.N. (2000). The effects of school climate on school disorder. The Annals of the American Academy of Political and Social Science, 567(1): 88-107.

Wright, R.E. (2000). Student evaluations and consumer orientation of universities. Journal of Nonprofit \& Public Sector Marketing, 8(1), 33-40. 
Yokuş, G., Ayçiçek, B., ve Yelken, T.Y. (2017). Üniversite öğrencilerinin hizmet kalite algılarının ve kurumsal aidiyet düzeylerinin incelenmesi: Eğitim fakültesi örneği. Karaelmas Eğitim Bilimleri Dergisi, 5(1).

Yousapronpaiboon, K. (2014). SERVQUAL: Measuring higher education service quality in Thailand. Procedia-Social and Behavioral Sciences, 116, 1088-1095.

Zullig, K.J., Koopman, T.M., Patton, J.M., \& Ubbes, V.A. (2010). School climate: Historical review, instrument development, and school assessment. Journal of Psychoeducational Assessment, 28(2): 139-152. 